\title{
ANALISIS KONFLIK PENGELOLAAN SUMBERDAYA ALAM DI KAWASAN TAMAN NASIONAL GUNUNG GEDE PANGRANGO
}

\section{Analysis of Conflict Management of Natural Resources in the National Park Gede Pangrango Mountain Area}

\author{
Anugerah Muhammad Zulfikar ${ }^{1)}$, Fredian Tonny Nasdian ${ }^{1)}$ \\ ${ }^{1)}$ Departemen Sains Komunikasi dan Pengembangan Masyarakat, Fakultas Ekologi Manusia, \\ Institut Pertanian Bogor, Darmaga Bogor 16680, Indonesia \\ Email: nugiezulfikar@gmail.com; frediantonny@apps.ipb.ac.id
}

\begin{abstract}
Conflict can't be separated from the activity of community life and both are integrated. Humans will make efforts in order to fulfill their needs, including in terms of natural resources. Conservation areas or better known as the national park is one of the areas most prone to conflict over natural resources. This study aimed to analyze reality of conflict, the factors causing conflicts, the impact of conflict, the relationship of factors causing conflict with the intensity of emerging conflict and the forms of conflict resolution in the park area. This research is a quantitative research was supported by qualitative data with the instrument questionnaires and in-depth interview guide. The problem between farmers and the park is caused by the change of status of Perhutani area into Gunung Gede Pangrango National Park. This transformation changed rules of the people who initially worked on land in the region to be stalled. The conflicts natural resource issues until 2016 increasingly complex due to intimidation received by farmers every year. In resolving conflicts, researchers provide the idea of Community Based Conflict Management (CBCM) as a method of reducing conflict.
\end{abstract}

Keywords: Analysis of conflict, natural resources, national parks

\section{ABSTRAK}

Konflik tidak bisa dipisahkan dari aktivitas kehidupan bermasyarakat dan keduanya saling berintegrasi. Manusia akan melakukan berbagai usaha agar kebutuhan hidupnya dapat tercukupi termasuk dalam hal sumberdaya alam. Kawasan konservasi atau yang lebih dikenal dengan sebagai taman nasional merupakan salah satu daerah yang paling rawan terjadi konflik sumberdaya alam. Penelitian ini bertujuan untuk menganalisis realitas konflik, faktor-faktor penyebab konflik, hubungan faktor-faktor penyebab konflik dengan intensitas konflik emerging dan gagasan penyelesaian konflik di kawasan Taman Nasional Gunung Gede Pangrango. Jenis penelitian ini adalah penelitian kuantitatif didukung oleh data kualitatif dengan instrumen kuesioner dan panduan wawancara mendalam. Permasalahan antara petani penggarap dengan pihak taman nasional disebabkan oleh adanya perubahan status kawasan Perhutani menjadi Taman Nasional Gunung Gede Pangrango. Perubahan ini merubah landasan pijak masyarakat yang awalnya menggarap lahan di kawasan menjadi terhenti. Konflik permasalahan sumber daya alam hingga Tahun 2016 semakin kompleks akibat adanya intimidasi yang diterima petani setiap tahunnya. Dalam menyelesaikan konflik, peneliti memberikan gagasan Manajemen Konflik Berbasis Komunitas (CBCM) sebagai metode peredam konflik.

Kata Kunci: Analisis konflik, sumberdaya alam, taman nasional

\section{PENDAHULUAN}

Kawasan-kawasan konservasi termasuk taman nasional di seluruh Indonesia mempunyai permasalahan yang mengancam kelestariannya. Permasalahan tersebut diantaranya adalah tumpang tindih kepentingan dari berbagai pihak, belum adanya kesamaan persepsi mengenai fungsi, kedudukan dan peran Taman Nasional di mata masyarakat dan pihak terkait lainnya (Mangindaan 1999). Adanya permasalahan tersebut yang terus menerus terjadi, memunculkan situasi konflik yang timbul diantara pemangku kepentingan, baik yang terwujud dalam bentuk konflik latent, maupun manifest. Konflik muncul bersumber dari kenyataan akan adanya unsur-unsur dalam setiap masyarakat 
yang saling bertentangan. Konflik adalah relasi sosial antar aktor sosial yang ditandai oleh pertentangan atau perselisihan dan kemarahan, baik dinyatakan secara terbuka ataupun tidak, dalam rangka mencapai keinginan atau tujuan masingmasing (Kinseng 2013).

Menurut Wulan et al. (2004), faktor utama penyebab konflik di kawasan konservasi adalah penetapan suatu kawasan konservasi yang biasanya dilakukan sepihak oleh pemerintah tanpa melibatkan masyarakat, dan pihak-pihak terkait. Namun hal tersebut dilakukan bukan tanpa alasan. Kekhawatiran akan semakin menurunnya fungsi hutan yang lebih tinggi, dan dengan memperhatikan keberlanjutan ekologi, ekonomi, dan sosial kawasan hutan sebagai kawasan penyangga kehidupan, mendorong pemerintah mengambil kebijakan baru dengan mengubah status dan fungsi hutan pada kawasan Taman Nasional yang semula berfungsi sebagai hutan produksi dan lindung menjadi Kawasan Konservasi.

Berdasarkan penelitian yang dilakukan Marina dan Dharmawan (2011), penyebab konflik kehutanan yang terjadi di Taman Nasional Gunung HalimunSalak disebabkan oleh empat sumber perbedaan, yaitu: perbedaan persepsi, kepentingan, tata nilai, dan akuan hak kepemilikan. Namun, permasalahan utama dalam konflik di Taman Nasional Gunung Halimun-Salak terletak pada perbedaan dalam akuan hak kepemilikan (klaim), terjadi ketika pihak taman nasional menganggap bahwa kawasan Taman Nasional Gunung Halimun-Salak sebagai milik negara karena tidak terbebani hak atas tanah, sedangkan masyarakat adat menganggap bahwa kawasan Gunung Halimun adalah milik adat, karena sudah diwariskan oleh leluhur untuk anak-cucu mereka.

Dari Tahun 1997 sampai dengan Tahun 1999 konflik di sektor kehutanan cenderung meningkat cukup tajam. Jumlah konflik meningkat hampir empat kali lipat pada Tahun 1999 dibandingkan dengan Tahun 1997. Pada Tahun 2000 jumlah konflik melonjak drastis sampai 153 kejadian. Angka ini mengalami penurunan kembali pada Tahun 2001 dan 2002. Namun berdasarkan data sampai dengan bulan Juni 2003, jumlah konflik cenderung meningkat kembali (Wulan et al. 2004). Konflik dengan masyarakat sekitar hutan dapat terjadi karena selama ini pembangunan kehutanan belum memperhatikan kondisi sosial ekonomi masyarakat. Ketertinggalan dari segi ekonomi menyebabkan timbulnya sikap bertahan dari masyarakat terhadap pihak luar yang mengelola hutan.

Penutupan akses masyarakat, pemindahan permukiman, dan penegakan hukum merupakan upaya pemenuhan ketentuan UU Nomor 5 Tahun 1990 (Dephut 1990) dan Peraturan Pemerintah Nomor 68 Tahun 1998 (Dephut 1998) yang menyatakan bahwa di dalam kawasan taman nasional tidak dibenarkan adanya kegiatan-kegiatan yang mengancam kelestarian kawasan. Keberadaan permukiman merupakan bentuk gangguan dan ancaman terhadap kelestarian kawasan sehingga harus dikeluarkan dari dalam kawasan dan disertai pemindahan permukiman. Namun demikian, alternatif solusi ini sangat berat untuk dilakukan karena untuk pelaksanaannya memerlukan pendanaan yang sangat besar dan kemungkinan adanya resistensi yang besar dari masyarakat (Prabowo et al. 2010).

Taman Nasional Gunung Gede Pangrango (TNGGP) merupakan salah satu taman nasional di Indonesia. Kawasan TNGGP merupakan perwakilan hutan hujan tropis dataran tinggi dengan ketinggian 1000 meter hingga 3019 meter di atas permukaan laut. Pengelolaan TNGGP dilaksanakan oleh Balai Besar Taman Nasional Gunung Gede Pangrango (BB TNGGP) berdasarkan Keputusan Menteri Kehutanan No.6186/Kpts-II/2003, Tanggal 10 Juni 2003. Kawasan TNGGP awalnya memiliki luas 15196 ha, dan secara administratif terletak di tiga wilayah kabupaten, yaitu Kabupaten Bogor (4.514,73 ha), Kabupaten Sukabumi (6.781,98), dan Kabupaten Cianjur (3.599,29 ha). Setelah adanya perluasan kawasan maka luasnya menjadi 21975 ha sesuai Surat Keputusan Menteri Kehutanan No.174/Kpts-II/tanggal 10 Juni 2003 (Karsodi 2007).

Sebelum dikelola oleh Balai Besar Taman Nasional Gunung Gede Pangrango, wilayah hutan dikelola oleh Perum Perhutani. Melimpahnya sumberdaya alam khususnya lahan pertanian membuat masyarakat Desa Pasir Buncir mengandalkan pertanian sebagai mata pencaharian dengan 
sebanyak 2788 orang (76.25 persen) di bidang pertanian di sekitar kawasan TNGGP. Adanya ketergantungan masyarakat petani di Kampung Cipecang dengan menggunakan lahan yang termasuk dalam kawasan konservasi menimbulkan keresahan bagi pengelola Taman Nasional Gunung Gede Pangrango pasca penetapan kawasan. Hal tersebut dikarenakan didalam pengelolaan kawasan konservasi masyarakat tidak diperbolehkan mengelola sumberdaya alam yang sesuai dengan ketetapan UU Nomor 5 Tahun 1990 (Dephut). Adanya ketetapan dalam perubahan kawasan menjadi area konservasi berdampak bagi masyarakat yang berada di sekitar maupun di dalam kawasan taman nasional.

Menurut Mufrizal (2010), perubahan fungsi kawasan dari hutan lindung menjadi hutan konservasi dengan nama Taman Nasional menimbulkan berbagai permasalahan sosial, ekonomi, dan membawa konsekuensi yuridis dalam hal pengelolaannya. Hal ini dikarenakan hampir tidak ditemukan landasan pijak bagi masyarakat untuk bertahan mengelola hutan yang mengakibatnya masyarakat sekitar merasa dirugikan. Berdasarkan penelitian Agustinawati (2011) masyarakat Desa Pasir Buncir hidup bergantung pada sumberdaya tersebut dengan mendapatkan penghasilan pendapatan rumah tangga sekitar 25.38 persen dari dalam kawasan TNGGP. Adanya penghentian beraktivitas oleh pengelola taman nasional berujung pada benturan antara masyarakat dengan taman nasional yang menimbulkan konflik. Sikap dan reaksi petani bermunculan hingga mencuat untuk memperjuangkan lahan sumber penghidupannya. Adanya penguasaan tanah memunculkan perlawanan kepada pihak taman nasional agar masyarakat tetap dapat mengakses. Namun perlawanan yang dilayangkan tentu tidak hanya oleh pihak pemanfaat (pengguna) yaitu petani, namun bisa jadi komunitas, pemerintah, swasta ikut terlibat sebagai akibat perluasan wilayah TNGGP yang mengambil hak atas penguasaan tanahnya. Berdasarkan pemaparan yang telah dijabarkan, fenomena ini memunculkan suatu pertanyaan yaitu bagaimana permasalahan konflik yang terjadi dalam pengelolaan sumber daya alam di Taman Nasional Gunung Gede Pangrango?
Kompleksitas aktor-aktor yang terlibat dalam pengelolaan sumberdaya alam di kawasan Taman Nasional Gunung Gede Pangrango menyebabkan banyaknya terjadi benturan-benturan yang dapat memicu terjadinya konflik dalam pengelolaan sumberdaya alam tersebut akibat penegakan yang dilakukan pengelola taman nasional (Hidayah 2012). Manusia melakukan berbagai usaha dalam memenuhi kebutuhan dengan merealisasikan haknya yang merupakan bagian dari komunal, sering sekali terjadi benturan-benturan antara pemenuhan hak-hak tersebut. Benturan-benturan tersebut menimbulkan ketidakadilan dan memicu tumbuhnya konflik antarmanusia (Marina dan Dharmawan 2011). Realitas konflik menggambarkan proses konflik melalui tindakan dan interaksi dari aktor-aktor yang ada, dengan masing-masing aktor tersebut secara terus menerus realitas dialami secara subjektif. Konflik yang terjadi antara masyarakat khususnya petani dengan pengelola taman nasional bisa sering maupun tidak, sesuai dengan tingkat keterlibatannya dalam konflik melalui kegiatan yang dilakukan dalam mengupayakan hak atas penguasaan lahan yang dimilikinya. Berdasarkan pemaparan tersebut, hal ini memunculkan pertanyaan, bagaimana realitas konflik sumberdaya alam yang terjadi di kawasan Taman Nasional Gunung Gede Pangrango?

Konflik sosial dapat dikonsepsikan sebagai hubungan sosial yang tidak harmonis sebagai konsekwensi dari perbedaan nilai, kepentingan dan tindakan yang terdapat dalam masyarakat terkait dengan pemanfaatan dan pengelolaan lingkungan (Kausar 2010). Konflik dalam pemanfaatan lahan di kawasan Taman Nasional Gunung Gede Pangrango terjadi karena adanya perbedaan pemahaman antara masyarakat dengan pemerintah tentang peruntukan lahan dalam kawasan hutan. Apabila dibiarkan begitu saja dengan ketidaksesuaian yang terus terjadi, maka akan ada bentuk konflik yang lebih besar. Berdasarkan pemaparan tersebut, hal ini memunculkan pertanyaan, faktor-faktor apa yang menyebabkan timbulnya konflik pengelolaan sumberdaya alam di kawasan Taman Nasional Gunung Gede Pangrango?

Adanya pembentukan Taman Nasional Gunung Gede Pangrango menimbulkan konflik sosial. Hal ini disebabkan masyarakat di sekitar taman nasional 
ditutup aksesnya untuk memanfaatkan sumberdaya alam yang ada didalamnya. Apabila ditutup, masyarakat sekitar khususnya petani menjadi kehilangan sumber penghasilan untuk mencukupi kebutuhannya. Berdasarkan pemaparan tersebut, hal ini memunculkan pertanyaan, bagaimana dampak konflik yang dirasakan petani sebagai akibat konflik pengelolaan sumberdaya alam di kawasan Taman Nasional Gunung Gede Pangrango?

Perbedaan permasalahan menimbulkan konflik antara petani dengan pihak Taman Nasional Gunung Gede Pangrango semakin kompleks. Hal ini akan semakin bertambah apabila permasalahan tersebut tidak mampu diselesaikan sehingga terjadi eskalasi konflik yang semakin meningkat. Salah satunya, hal ini didasari dengan tingkat keuntungan yang didapat dari hasil sumberdaya alam yang berada di kawasan taman nasional, sehingga petani intensif ikut serta dalam berbagai kegiatan konflik untuk mengadvokasi lahan sumber penghidupannya agar tidak direbut oleh pihak TNGGP. Berdasarkan pemaparan tersebut, maka pertanyaannya, bagaimana hubungan faktor-faktor penyebab konflik dengan intensitas konflik emerging dalam konflik sumberdaya alam di kawasan Taman Nasional Gunung Gede Pangrango?

Wulan et al. (2004) mengungkapkan penyelesaian konflik merupakan suatu upaya atau inisiatif yang dilakukan untuk mengatasi dan mencari jalan keluar dari suatu peristiwa konflik. Inisiatif ini bisa datang dari para pihak yang terlibat dalam konflik baik masyarakat (petani), pemerintah, ataupun Taman Nasional Gunung Gede Pangrango, sehingga didalamnya terjadi negosiasi untuk mencapai kesepakatan yang menguntungkan bersama. Konflik yang muncul dalam pengelolaan sumberdaya alam bukan untuk dihilangkan tetapi perlu dicarikan solusinya (Kadir et al. 2013). Berdasarkan pemaparan tersebut, hal ini memunculkan pertanyaan, bagaimana gagasan penyelesaian konflik sebagai resolusi konflik di kawasan Taman Nasional Gunung Gede Pangrango?

Tujuan umum dari penelitian adalah menganalisis permasalahan permasalahan konflik yang terjadi dalam pengelolaan sumber daya alam di Taman Nasional Gunung Gede Pangrango. Sedangkan tujuan khusus penelitian adalah sebagai berikut: Menganalisis (1) realitas konflik pengelolaan sumberdaya alam yang terjadi pada di kawasan Taman Nasional Gunung Gede Pangrango (2) Menganalisis faktor-faktor yang menyebabkan timbulnya konflik pengelolaan sumberdaya alam di kawasan Taman Nasional Gunung Gede Pangrango (3) Menganalisis dampak konflik yang dirasakan petani sebagai akibat konflik pengelolaan sumberdaya alam di kawasan Taman Nasional Gunung Gede Pangrango (4) Menganalisis hubungan faktor-faktor penyebab konflik dengan intensitas konflik emerging pada konflik sumberdaya alam di kawasan Taman Nasional Gunung Gede Pangrango (5) Menganalisis gagasan penyelesaian konflik sebagai resolusi konflik di kawasan Taman Nasional Gunung Gede Pangrango.

\section{PENDEKATAN TEORITIS}

\section{Konflik Sumberdaya Alam}

Fisher et al. (2001) berpendapat bahwa konflik adalah hubungan antara dua pihak atau lebih (individu atau kelompok) yang memiliki, atau merasa memiliki sasaran-sasaran yang tidak sejalan. Konflik menurut Fuad dan Maskanah (2000) yaitu benturan yang terjadi antara dua pihak atau lebih yang disebabkan adanya perbedaan budaya, nilai, status, kekuasaan dan kelangkaan sumberdaya, dimana masing-masing pihak mempunyai kepentingan yang sama terhadap sumberdaya. Sumberdaya alam merupakan salah satu potensi kuat dalam menciptakan situasi konflik. Sumberdaya alam memberikan penghidupan bagi pemanfaat dalam melakukan aktivitas maupun memperoleh manfaat ekonomis untuk memenuhi kebutuhannya.

\section{Faktor-Faktor Penyebab Konflik}

Menurut Fuad dan Maskanah (2000) menjelaskan konflik dapat dikelompokkan dan dianalisis dengan menggunakan ruang-ruang konflik sebagai berikut ini: (1) Konflik data. Terjadi ketika orang kekurangan informasi, mendapat informasi yang salah, tidak sepakat mengenai data yang relevan, menterjemahkan informasi dengan cara yang berbeda. (2) Konflik kepentingan. Disebabkan oleh persaingan kepentingan yang dirasakan atau secara nyata memang tidak bersesuai dengan yang diinginkan. (3) Konflik hubungan antar manusia. Terjadi karena adanya emosi-emosi negatif yang kuat, salah persepsi atau stereotype, salah komunikasi atau tingkah laku negatif yang berulang 
(repititif). (4) Konflik nilai. Disebabkan oleh sistemsistem kepercayaan yang tidak bersesuaian, mungkin hal itu hanya dirasakan atau memang sesungguhnya ada. (5) Konflik struktural. Terjadi ketika ketimpangan untuk melakukan akses dan kontrol terhadap sumberdaya.

\section{Aktor-Aktor dalam Konflik}

Banyaknya aktor yang terlibat bukan berarti distribusi dalam manfaat sumberdaya alam juga turut banyak ataupun merata dengan baik. Oleh karena itu, konflik pun muncul dengan melibatkan banyak pihak dari luar, baik untuk mempertahankan kepentingan masing-masing ataupun untuk pendampingan konflik. Oktaviana (2015) menyebutkan aktor-aktor dalam konflik diantaranya: (1) Masyarakat Lokal (2) Swasta (Private Sector) (3) Pemerintah/Negara (State) (4) Kelembagaan Masyarakat.

\section{Intensitas Konflik}

Menurut Fuad dan Maskanah (2000), konflik yang terjadi dapat berupa konflik latent, konflik emerging, dan konflik manifest. Konflik latent dicirikan dengan adanya tekanan-tekanan yang belum terlihat sehingga tidak muncul ke permukaan. Selain itu, biasanya ada pihak yang terlibat belum menyadari adanya konflik. Konflik emerging adalah pihakpihak yang terlibat dalam konflik mengakui adanya perselisihan yang terjadi dengan konteks permasalahan yang telah diketahui bersama secara jelas, namun dalam penyelesaian masalahnya sendiri belum ada. Konflik manifest adalah pihak-pihak terlibat secara aktif dalam konflik, dan melakukan adanya aksi tindakan yang menunjukkan pertikaian dalam memperjuangkan kepentingannya. Konflik ini bisa jadi pihak yang bertikai sudah mulai melakukan upaya penyelesaian.

\section{Dampak Konflik}

Menurut Karlinda (2015) dampak konflik dapat disebabkan oleh beberapa faktor, seperti (1) penurunan luas penguasaan lahan, (2) keresahan petani, (3) Persepsi negatif petani, (4) Kesadaran petani dan (5) peningkatan kohesivitas kelompok.

\section{Penyelesaian Konflik}

Mengutip Condliffe (1991) dalam Marina dan Dharmawan (2011) mengenai resolusi konflik, terdapat delapan prosedur umum dalam rangka penyelesaian konflik, yaitu: lumping it, avoidance or exit, coercion, negotiation, concilliation, mediation, arbitration, adjudication. Dari kedelapan prosedur umum penyelesaian konflik di atas, hanya butir negoisasi, konsiliasi dan mediasi yang merupakan penyelesaian konflik di luar pengadilan yang dipandang kondusif. Hal ini dikarenakan ketiganya mengandung unsur win-win solution yang sifatnya lebih langgeng.

\section{Kerangka Pemikiran}

Munculnya penetapan kawasan konservasi Taman Nasional Gunung Gede Pangrango menjadi pemicu utama penyebab konflik. Hal ini apabila dianalisis, konflik dapat disebabkan petani Kampung Cipecang tidak diperkenankan untuk menggarap lahan di kawasan TNGGP.

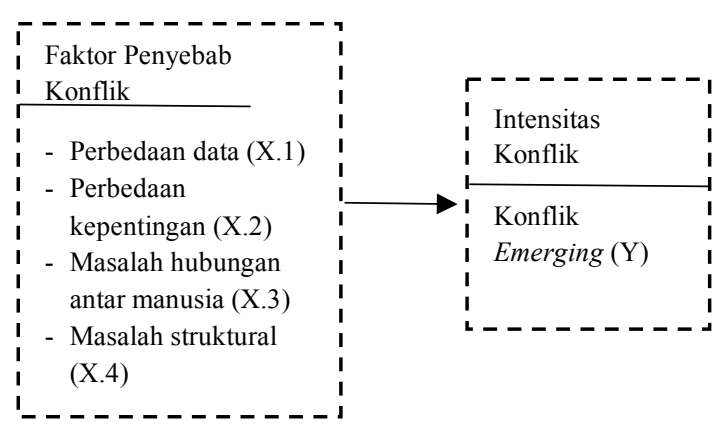

Gambar 1 Bagan Kerangka Berfikir

\section{METODE PENELITIAN}

Penelitian yang dilakukan termasuk ke dalam penelitian deskriptif dan penelitian penjelasan (explanatory research). Penelitian deskriptif digunakan untuk memperoleh informasi yang lebih mendalam mengenai kondisi sosial atau fakta suatu peristiwa di daerah tertentu. Penelitian ini menggunakan pendekatan data kuantitatif dengan didukung data kualitatif. Faktor-faktor penyebab konflik dan intensitas konflik emerging akan diukur secara kuantitatif. Penelitian ini dilakukan di Kampung Cipecang, Desa Pasir Buncir, Kecamatan Caringin, Kabupaten Bogor. Pemilihan lokasi penelitian dilakukan secara sengaja (purposive).

Jenis data yang digunakan dalam penelitian ini adalah data primer dan sekunder. Data primer diperoleh melalui penelitian langsung di lapangan dengan menggunakan instrumen berupa kuesioner. Isi kuesioner ditujukan kepada petani penggarap Kampung Cipecang, Desa Pasir Buncir yang terlibat 
dalam konflik dengan menggunakan teknik pendekatan kuantitatif untuk melihat penyebab konflik dan intensitas konflik emerging. Wawancara mendalam juga dilakukan dengan beberapa petani penggarap Kampung Cipecang, aparat Desa Pasir Buncir, LSM dan pihak Balai Besar Taman Nasional Gunung Gede Pangrango untuk menggali lebih banyak tentang konflik sumberdaya alam yang telah berlangsung selama ini. Data sekunder diperoleh dari kantor desa mengenai profil desa, dan dari Balai Besar Taman Nasional Gunung Gede Pangrango mengenai profil Taman Nasional Gunung Gede Pangrango.

Penelitian ini menggunakan sumber data dari responden dan informan melalui survei (kuesioner) dan wawancara mendalam. Unit analisis penelitian ini adalah individu petani penggarap yang terkait dalam konflik. Responden dalam penelitian ini adalah petani penggarap Kampung Cipecang, Desa Pasir Buncir yang melakukan penggarapan di kawasan Taman Nasional Gunung Gede Pangrango (TNGGP). Populasi dalam penelitian ini adalah seluruh petani penggarap yang terlibat dalam konflik pengelolaan sumberdaya alam di Taman Nasional Gunung Gede Pangrango. Berdasarkan informasi yang diperoleh dari lapang, petani yang terlibat sebanyak 37 orang. Seluruh petani penggarap tersebut dipilih menjadi responden (sensus). Sedangkan pemilihan terhadap informan dilakukan secara sengaja (purposive).

Data yang diperoleh dari penelitian ini berupa data kuantitatif dan data kualitatif. Data yang diperoleh secara kuantitatif melalui kuesioner diolah dengan menggunakan program Microsoft Excel 2013 dan SPSS 16 for Windows. Kemudian IBM SPSS Statistic 16 for windows digunakan untuk melihat hubungan yang nyata antara faktor penyebab konflik dengan intensitas konflik. Korelasi dapat menghasilkan angka positif (+) dan negatif (-). Korelasi positif menunjukkan hubungan yang searah antara dua variabel yang diuji, yang berarti semakin besar variabel bebas (variabel independen) maka semakin besar pula variabel terikat (variabel dependen). Sementara itu korelasi negatif menunjukkan hubungan yang tidak searah, yang berarti jika variabel bebas besar maka variabel terikat menjadi kecil. Rumus korelasi Rank Spearman adalah sebagai berikut: $r_{S}=1-\frac{6 \sum d i^{2}}{n\left(n^{2}-1\right)}$

\section{HASIL DAN PEMBAHASAN}

\section{Realitas Konflik}

\section{Aktor-Aktor yang berkonflik}

Dalam penelitian ini, aktor yang berkonflik terbagi menjadi empat, yakni pengelola Taman Nasional Gunung Gede Pangrango, petani penggarap Kampung Cipecang, aparat Desa Pasir Buncir, dan Rimbawan Muda Indonesia (RMI).

a. Pengelola Taman Nasional Gunung Gede Pangrango

Pihak Taman Nasional Gunung Gede Pangrango sejak Keputusan Menteri Kehutanan No.6186/Kpts-II/2003, di Tahun 2003 terkait perubahan status kawasan menjadi Taman Nasional meminta agar masyarakat yang berada di dalam kawasan TNGGP untuk tidak lagi beraktivitas. Hal ini begitu juga bagi petani Kampung Cipecang untuk tidak lagi merambah kawasan hutan, supaya kawasan yang telah menjadi wilayah konservasi tersebut keanekaragaman yang ada didalamnya dapat terlidungi. Selain itu, kegiatan itu dilakukan sebagai upaya pemenuhan ketentuan UU Nomor 5 Tahun 1990 (Dephut 1990) dan Peraturan Pemerintah Nomor 68 Tahun 1998 (Dephut 1998) yang menyatakan bahwa di dalam kawasan taman nasional tidak dibenarkan adanya kegiatankegiatan yang mengancam kelestarian kawasan.

\section{b. Petani Penggarap Kampung Cipecang}

Hampir sekitar 80 persen jumlah rumah tangga Kampung Cipecang berprofesi sebagai petani penggarap di kawasan TNGGP (Gambar 12). Jumlah petani yang menggarap lahan tersebut berjumlah 37 orang. Petani penggarap bereaksi negatif terhadap pihak TNGGP akibat terjadi perselisihan yang dikarenakan perebutan sumber daya alam di kawasan taman nasional. Petani mengganggap wilayah tersebut yang merupakan sumber pencaharian masyarakat sejak dahulu dan lahan tersebut diwariskan oleh nenek moyangnya secara turun-temurun jauh sebelum taman nasional ada. Petani merasa pihak TNGGP seharusnya tidak melarang mereka untuk 
melakukan aktivitas seperti biasanya dalam menggarap lahan.

c. Aparat Desa Pasir Buncir

Ketidaktahuan aparat desa mengenai konflik yang ada dikarenakan faktor kepengurusan desa yang baru berganti pada Tahun 2013, sehingga mereka mengaku tidak mengetahu informasi sebelumnya. Namun pihak Pemerintah Desa Pasir Buncir sering menjalin interaksi dan koordinasi dengan Pihak Taman Nasional Gunung Gede Pangrango. Pihak TNGGP berkoordiansi dalam memberikan sosialisasi di desa mengenai penanaman pohon. Kegiatan sosialisasi tersebut baru dilakukan di Kampung Lengkong saja. Sementara itu pemerintah sebelumnya menjalin kerja sama dengan Pihak TNGGP dalam membantu masyarakat Kampung Wangung Jaya mengganti alih profesi dari petani penggarap menjadi peternak. Hal ini dilakukan karena untuk menghindari konflik sehingga pihak TNGGP memberikan pekerjaan lapangan yang baru. Namun aparat desa mengaku kegiatan tersebut belum sama sekali dilakukan di Kampung Cipecang.

d. Rimbawan Muda Indonesia

RMI masuk ke Kampung Cipecang Tahun 2014 untuk membantu masyarakat dalam mempertahankan lahan garapan petani dari Pihak TNGGP. RMI membuat rapat yang membahas mengenai kegiatan yang tidak diperbolehkan didalam kawasan konservasi seperti menebang pohon di wilayah yang bukan lahan garapannya, arahan/motivasi untuk tetap menggarap dan melakukan pengukuran terhadap lahan yang petani garap di kawasan Taman Nasional Gunung Gede Pangrango. Selain itu juga dilakukan pengukuran terhadap lahan petani untuk mengetahui luas lahan yang digarap dan memberikan batas-batas antara petani dengan petani lainnya. Hal ini untuk mencegah konflik internal antar petani penggarap.

\section{Sumber Konflik}

Petani penggarap dan pihak TNGGP terjadi perselisihan dikarenakan perebutan SDA berupa lahan pertanian dan perkebunan yang berada di kawasan taman nasional. Petani penggarap mengganggap wilayah tersebut merupakan peninggalan nenek moyangnya secara turun-temurun jauh sebelum taman nasional ada, sehingga pihak TNGGP seharusnya tidak melarang mereka untuk melakukan aktivitas seperti biasanya dalam menggarap lahan. Pergantian kekuasaan dari Perhutani menjadi Taman Nasional berdasarkan Keputusan Menteri Kehutanan No.6186/KptsII/2003, di Tahun 2003 belum menyebabkan dampak bagi petani penggarap Kampung Cipecang karena penegakan kebijakan pelarangan aktivitas di kawasan TNGGP belum berjalan.

\section{Frekuensi dan Intensitas (Eskalasi) Konflik}

Intensitas konflik emerging petani dalam penelitian ini diukur berdasarkan pernah atau tidaknya mendapatkan perlakuan intimidasi, jumlah perlakuan intimidasi yang diterima, pernah atau tidaknya mengikuti pertemuan rapat dengan RMI, dan jumlah pertemuan rapat dengan RMI yang diikuti.

Tabel 1 Jumlah dan persentase responden menurut perlakuan intimidasi di Kampung Cipecang, Desa Pasir Buncir

\begin{tabular}{llcc}
\hline No & $\begin{array}{l}\text { Perlakuan } \\
\text { Intimidasi }\end{array}$ & $\begin{array}{c}\text { Jumlah } \\
\text { (orang) }\end{array}$ & $\begin{array}{c}\text { Persentase } \\
(\%)\end{array}$ \\
\hline 1 & Tidak Pernah & 27 & 73.0 \\
2 & Pernah & 10 & 27.0 \\
\hline & Total & 37 & 100.0 \\
\hline
\end{tabular}

Dari tabel 1 menunjukkan bahwa sebanyak 27 orang (73 persen) tidak pernah mendapatkan perlakuan intimidasi sehingga tingkat perlakuan intimidasi tergolong rendah. Hal ini terjadi dikarenakan responden hanya mengetahui petugas TNGGP datang dan melakukan intimidasi dari petani yang berada dilapangan saja. Kemudian informasi tersebut diberitahukan oleh petani lainnya dari satu ke petani lainnya.

Berdasarkan tabel 2, jumlah perlakuan intimidasi tergolong dalam intensitas yang rendah. Hal ini ditunjukkan dengan sebanyak 26 orang ( 70.3 persen) sama sekali tidak pernah mendapatkan intimidasi. Kemudian sebanyak 18.9 persen menyatakan pernah mendapatkan intimidasi sebanyak 1 kali. Sisanya hanya berkisar dibawah 11 persen saja. 
Tabel 2 Jumlah dan persentase responden menurut jumlah perlakuan intimidasi di Kampung Cipecang, Desa Pasir Buncir

\begin{tabular}{llcc}
\hline No & $\begin{array}{l}\text { Jumlah Perlakuan } \\
\text { Intimidasi }\end{array}$ & $\begin{array}{c}\text { Jumlah } \\
\text { (orang) }\end{array}$ & $\begin{array}{c}\text { Persentase } \\
(\%)\end{array}$ \\
\hline 1 & 0 & 26 & 70.3 \\
2 & 1 & 7 & 18.9 \\
3 & 2 & 1 & 2.7 \\
4 & 3 & 2 & 5.4 \\
5 & 4 & 0 & 0.0 \\
6 & 5 & 1 & 2.7 \\
\hline & Total & 37 & 100.0 \\
\hline
\end{tabular}

Tabel 3 menunjukkan bahwa pertemuan rapat yang diikuti responden dengan pihak RMI tergolong tinggi dengan sebanyak 23 orang (62.2 persen) pernah mengikuti rapat. Kebanyakan yang tidak mengikuti rapat adalah wanita maupun petani yang berada di usia muda.

Tabel 3 Jumlah dan persentase responden menurut pertemuan rapat di Kampung Cipecang, Desa Pasir Buncir

\begin{tabular}{llcc}
\hline No & $\begin{array}{l}\text { Pertemuan } \\
\text { Rapat }\end{array}$ & $\begin{array}{c}\text { Jumlah } \\
\text { (orang) }\end{array}$ & $\begin{array}{c}\text { Persentase } \\
(\%)\end{array}$ \\
\hline 1 & Tidak Pernah & 14 & 37.8 \\
2 & Pernah & 23 & 62.2 \\
\hline & Total & 37 & 100.0 \\
\hline
\end{tabular}

Dari Tabel 4 tersebut diketahui bahwa jumlah pertemuan rapat di dominasi oleh intensitas yang tergolong rendah karena sebanyak 37.8 persen tidak pernah hadir. Hal ini dikarenakan responden tidak secara rutin selalu mengikuti semua pertemuan rapat karena faktor kelelahan akibat pekerjaan maupun ada kegiatan lain.

Tabel 4 Jumlah dan persentase responden menurut pertemuan rapat di Kampung Cipecang, Desa Pasir Buncir

\begin{tabular}{llrc}
\hline No & $\begin{array}{l}\text { Jumlah } \\
\text { Pertemuan Rapat }\end{array}$ & $\begin{array}{c}\text { Jumlah } \\
\text { (orang) }\end{array}$ & $\begin{array}{c}\text { Persentase } \\
(\%)\end{array}$ \\
\hline 1 & 0 & 14 & 37.8 \\
2 & 1 & 8 & 21.6 \\
3 & 2 & 4 & 10.8 \\
4 & 3 & 4 & 10.8 \\
5 & 4 & 4 & 10.8 \\
6 & 5 & 3 & 8.1 \\
\hline & Total & 37 & 100.0 \\
\hline
\end{tabular}

\section{Konflik Emerging}

Berdasarkan hasil yang ditemukan di lapangan, konflik emerging ditentukan berdasarkan hasil penjumlahan skor empat indikator yakni dari pernah tidaknya mendapatkan perlakuan intimidasi, jumlah perlakuan intimidasi, pernah tidaknya mengikuti rapat dan jumlah mengikuti pertemuan rapat.

Tabel 5 Jumlah dan persentase responden menurut intensitas konflik emerging di Kampung Cipecang, Desa Pasir Buncir

\begin{tabular}{llcc}
\hline No & $\begin{array}{l}\text { Konflik } \\
\text { Emerging }\end{array}$ & $\begin{array}{c}\text { Jumlah } \\
\text { (orang) }\end{array}$ & $\begin{array}{c}\text { Persentase } \\
(\%)\end{array}$ \\
\hline 1 & Rendah & 18 & 48.6 \\
2 & Sedang & 13 & 35.1 \\
3 & Tinggi & 6 & 16.2 \\
\hline & Total & 37 & 100.0 \\
\hline
\end{tabular}

Sebagian besar tingkat intensitas konflik emerging tergolong rendah, yaitu sebanyak 18 orang (48.6 persen). Sebesar 35.1 persen atau sebanyak 13 orang memiliki tingkat intensitas konflik emerging rendah. Rendahnya konflik emerging yang terjadi antara petani penggarap dengan pihak Taman Nasional Gunung Gede Pangrango (TNGGP) dikarenakan hanya beberapa pihak saja yang merasa pernah bersentuhan langsung dengan pihak TNGGP.

\section{Faktor-Faktor Penyebab Konflik}

Berdasarkan hasil penelitian faktor-faktor penyebab konflik dikarenakan perbedaan data, perbedaan kepentingan, masalah hubungan antar manusia, dan masalah struktural.

\section{Perbedaan Data}

Tabel 6 Jumlah dan persentase responden menurut perbedaan data di Kampung Cipecang, Desa Pasir Buncir

\begin{tabular}{llll}
\hline No & Perbedaan Data & $\begin{array}{l}\text { Jumlah } \\
\text { (orang) }\end{array}$ & $\begin{array}{l}\text { Persentase } \\
(\%)\end{array}$ \\
\hline 1 & Rendah & 15 & 40.5 \\
2 & Sedang & 22 & 59.5 \\
3 & Tinggi & 0 & 0.0 \\
\hline & Total & 37 & 100.0 \\
\hline
\end{tabular}

Berdasarkan tabel 6, sebagian besar responden masuk kedalam kategori sedang, yakni sebanyak 22 orang (59.5 persen). Beberapa responden hanya mengetahui terjadi perbedaan informasi yang didapat 
dalam penentuan penetapan kawasan TNGGP dan batas-batas zonasi yang ditetapkan oleh taman nasional.

\section{Perbedaan Kepentingan}

Tabel 7 Tabel Jumlah dan persentase responden menurut perbedaan kepentingan di Kampung Cipecang, Desa Pasir Buncir

\begin{tabular}{llcc}
\hline No & $\begin{array}{l}\text { Perbedaan } \\
\text { Kepentingan }\end{array}$ & $\begin{array}{c}\text { Jumlah } \\
\text { (orang) }\end{array}$ & $\begin{array}{c}\text { Persentase } \\
(\%)\end{array}$ \\
\hline 1 & Rendah & 1 & 2.7 \\
2 & Sedang & 15 & 40.5 \\
3 & Tinggi & 21 & 56.8 \\
\hline & Total & 37 & 100.0 \\
\hline
\end{tabular}

Dari hasil Tabel 7 tersebut menunjukkan bahwa perbedaan kepentingan masuk kedalam kategori tinggi dengan 56 persen. Dapat dilihat bahwa perbedaan terjadi dikarenakan petani mengakses sumber daya lahan untuk memenuhi kebutuhan sehari-hari. Sedangkan pihak TNGGP berjuang untuk menjaga ekosistem yang ada dikawasan tersebut agar tidak mengalami pengrusakan.

\section{Masalah Hubungan antar Manusia}

Tabel 8 menunjukkan tingkat masalah hubungan antar manusia tergolong sedang dengan 59.5 persen (22 orang). Masalah timbul akibat petani pernah mendapat perlakuan yang kurang menyenangkan oleh pihak Taman Nasional Gunung Gede Pangrango dengan intimidasi saat berada disawah. Selain itu, adanya penangkapan salah satu petani juga menimbulkan kesan buruk petani kepada pihak taman nasional. Adanya cara komunikasi petugas taman nasional yang "melukai hati petani" dikarenakan merendahkan status petani maupun berbicara dengan intonasi yang tinggi.

Tabel 8 Jumlah dan persentase responden menurut masalah hubungan antar manusia di Kampung Cipecang, Desa Pasir Buncir

\begin{tabular}{llrc}
\hline No & $\begin{array}{l}\text { Masalah } \\
\text { Hubungan Antar } \\
\text { Manusia }\end{array}$ & $\begin{array}{c}\text { Jumlah } \\
\text { (orang) }\end{array}$ & $\begin{array}{c}\text { Persentase } \\
\text { (\%) }\end{array}$ \\
\hline 1 & Rendah & 6 & 16.2 \\
2 & Sedang & 22 & 59.5 \\
3 & Tinggi & 9 & 24.3 \\
\hline & Total & 37 & 100.0 \\
\hline
\end{tabular}

\section{Masalah Struktural}

Berdasarkan data tabel 9, masalah struktural tergolong tinggi, yakni 56.8 persen (21 orang). Responden menganggap masalah timbul akibat tidak adanya pertemuan yang melibatkan petani dalam membuat kebijakan yang berkaitan dengan lahan garapan mereka. Responden merasa pihak Taman Nasional Gunung Gede Pangrango dari awal tidak pernah melakukan pertemuan di Kampung Cipecang untuk berdiskusi kepada petani. Selain itu, adanya peraturan pelarangan penutupan kawasan yang secara sepihak dibuat oleh taman nasional membuat petani penggarap tidak akan dapat melakukan penggarapan lagi. Hal tersebut yang menyebabkan terjadinya perselisihan petani dengan pihak Taman Nasional Gunung Gede Pangrango akibat masalah struktural.

Tabel 9 Jumlah dan persentase responden menurut masalah struktural di Kampung Cipecang, Desa Pasir Buncir

\begin{tabular}{llcc}
\hline No & $\begin{array}{l}\text { Masalah } \\
\text { Struktural }\end{array}$ & $\begin{array}{c}\text { Jumlah } \\
\text { (orang) }\end{array}$ & $\begin{array}{c}\text { Persentase } \\
(\%)\end{array}$ \\
\hline 1 & Rendah & 5 & 13.5 \\
2 & Sedang & 11 & 29.7 \\
3 & Tinggi & 21 & 56.8 \\
\hline & Total & 37 & 100.0 \\
\hline
\end{tabular}

\section{Dampak Konflik dan Gagasan Penyelesaian Konflik}

\section{Dampak Konflik}

Dalam penelitian ini, berdasarkan hasil lapang diperoleh bahwa dampak konflik yang ditimbulkan akibat situasi konflik yang terjadi antara petani Kampung Cipecang dengan pihak Taman Nasional Gunung Gede Pangrango secara berkepanjangan terbagi menjadi dua yakni, keresahan dan ketakutan petani dan peningkatan kohesivitas kelompok.

a. Keresahan dan Ketakutan Petani

Bermula dari adanya penangkapan Pak SM pada Tahun 2003 oleh petugas Taman Nasional akibat transaksi kayu hasil hutan didalam Taman Nasional Gunung Gede Pangrango menimbulkan kesan buruk bagi petani penggarap Kampung Cipecang. Pasalnya, kayu yang dijual kepada orang lain berasal dari lahan garapnya sendiri. Pihak TNGGP berdalih bahwa pengambilan kayu didalam kawasan tersebut merupakan bentuk tindakan pelanggaran karena illegal. Akibat 
kejadian tersebut, beberapa petani menjadi resah saat akan melakukan panen atau mengambil kayu didalam lahan garapannya. Selain itu, beberapa petani juga mengaku berhati-hati apabila berada di lahan apabila sedang bertani. Mereka takut jika petugas TNGGP datang kemudian mengintimidasi mereka karena masih menggarap dilahan Taman Nasional Gunung Gede Pangrango.

b. Peningkatan Kohesivitas Kelompok

Petani penggarap Kampung Cipecang yang resah dan takut karena adanya penangkapan salah satu petani di lahannya sendiri menimbulkan dampak konflik yang positif bagi petani yakni peningkatan kohesivitas kelompok. Selain itu, akibat peneguran dan intimidasi yang dilakukan petugas Taman Nasional Gunung Gede Pangrango menjadikan kohesitivas mereka semakin meningkat. Adanya pembicaraan dari satu petani ke petani lainnya mengenai kejadian tersebut yang ada dilapangan membuat petani lainnya menjadi merasa iba sehingga akan membantu rekannya apabila terjadi kejadian yang serupa. Hal ini dibuktikan dengan saat terjadi penangkapan Pak SM, beberapa petani langsung datang untuk meminta melepaskan Pak SM melalui protes keras dan aksi. Sementara itu, melalui rapat yang dilakukan oleh petani penggarap Kampung Cipecang dengan RMI pada Tahun 2014 hingga Tahun 2016, menjadikan peningkatan solidaritas antar petani akibat adanya persamaan nasib.

\section{Hubungan Antara Faktor-Faktor Penyebab Konflik dengan Intensitas Konflik Emerging}

Peneliti ingin mengkaji hubungan variabel yang terdapat pada faktor penyebab konflik, sebagai asal mula timbulnya konflik antara petani penggarap Kampung Cipecang dengan pihak Taman Nasional Gunung Gede Pangrango terhadap intensitas konflik emerging melalui uji statistik menggunakan aplikasi SPSS version 16. Variabel faktor penyebab konflik sebagai variabel x yang diuji yakni perbedaan data, perbedaan kepentingan, masalah hubungan antar manusia, dan masalah struktural. Sementara itu, variabel y yakni intensitas konflik emerging.
Tabel 10 Hasil uji statistika Rank Spearman antara faktor penyebab konflik dengan intensitas konflik emerging

\begin{tabular}{lcc}
\hline \multirow{2}{*}{$\begin{array}{c}\text { Faktor Penyebab } \\
\text { Konflik }\end{array}$} & \multicolumn{2}{c}{$\begin{array}{c}\text { Intensitas Konflik } \\
\text { Emerging }\end{array}$} \\
\cline { 2 - 3 } & $\begin{array}{c}\text { Koefisien } \\
\text { korelasi }\end{array}$ & Sig \\
\hline Perbedaan Data & $379^{*}$ & 010 \\
Perbedaan Kepentingan & $465^{* *}$ & 002 \\
Masalah Hubungan & $524^{* *}$ & 000 \\
Antar Manusia & & \\
Masalah Struktural & $512^{* *}$ & 001 \\
\hline
\end{tabular}

Peneliti menganalisis hubungan antara faktor-faktor penyebab konflik dengan intensitas konflik emerging. Berdasarkan hasil analisis, diketahui bahwa terdapat hubungan yang sedang antara perbedaan data dengan intensitas konflik emerging sebesar 0.379 . Petani penggarap menganggap adanya perbedaan pemahaman yang berdasarkan informasi yang berbeda. Mereka hanya mendapatkan informasi dari satu petani ke petani lainnya, sedangkan pihak TNGGP tidak pernah datang untuk memberikan sosialisasi. Selanjutnya, perbedaan kepentingan terdapat hubungan kuat dengan intensitas konflik emerging dengan hasil uji korelasi sebesar 0.465. Petani menginginkan terus melakukan penggarapan untuk menghidupi keluarganya sehari-hari, sedangkan pihak TNGGP berjuang melakukan penutupan pada lahan garapan petani agar kelestarian ekosistem dalam kawaasan konservasi tetap terjaga. Pada masalah hubungan antar manusia terdapat hubungan dengan intensitas konflik emerging dengan hubungan nyata yang kuat sebesar 0.524. Masalah timbul akibat adanya cara komunikasi pihak TNGGP yang dianggap melukai hati petani. Sementara itu, terdapat hubungan yang kuat antara masalah struktural dengan intensitas konflik emerging sebesar 0.512. Petani penggarap Kampung Cipecang merasa bahwa mereka memiliki kuasa untuk menggarap lahan di dalam kawasan TNGGP karena faktor sejarah.

\section{Gagasan Penyelesaian Konflik}

Peneliti memberikan gagasan penyelesaian konflik sebagai solusi untuk mengakhiri konflik antara petani penggarap Kampung Cipecang dengan Taman Nasional Gunung Gede Pangrango yang sudah berlangsung lama. Upaya penyelesaiaan konflik belum dilaksanakan karena adanya perasaan curiga 
dari masing-masing pihak sehingga apabila ingin melaksanakan pertemuan sulit terlaksana. Oleh karena itu, diperlukan pihak ketiga yang bersifat netral untuk dapat merealisasikan pertemuan yang dapat menyelesaikan konflik antar mereka sehingga diperlukan community based conflict manajement (CBCM) atau manajemen konflik berbasis komunitas sebagai strategi dalam menyelesaikan konflik yang terus berkelanjutan. Kegiatan yang ada dalam CBCM yakni mempertemuan antar pihakpihak yang berkonflik dan menggunakan forum tersebut sebagai aktivitas yang secara nyata membicarakan pokok permasalahan. Peneliti menawarkan pihak ketiga dapat melangsungkan kegiatan di Aula Balai Desa Pasir Buncir sebagai lokasi yang strategis.

Kemudian, cara mediasi menjadi salah satu cara dalam menyelesaikan konflik antara petani penggarap Kampung Cipecang dengan pihak Taman Nasional Gunung Gede Pangrango melalui adanya pihak ketiga. Kehadiran pihak ketiga sebagai mediator dalam mediasi ini diharapkan menjadi solusi untuk mempertemukan kedua pihak yang sulit dipertemukan akibat adanya rasa saling curiga. Pihak ketiga yang dirumuskan dapat berasal dari lembaga swadaya masyarakat (LSM) Rimbawan Muda Indonesia, Pemerintah Desa Pasir Buncir, maupun akademisi. Melalui metode CBCM dalam pengelolaan konflik akibat perebutan sumber daya alam di kawasan TNGGP, diharapkan mampu mengakomodasikan berbagai kepentingan aktor sehingga terciptanya keselarasan antar pihak.

\section{SIMPULAN DAN SARAN}

\section{Simpulan}

Simpulan umum dalam penelitian ini adalah permasalahan yang timbul antara petani penggarap dengan pihak Taman Nasional Gunung Gede Pangrango disebabkan oleh adanya perubahan status kawasan Perhutani menjadi Taman Nasional Gunung Gede Pangrango yang berdasarkan Keputusan Menteri Kehutanan No.6186/Kpts-II/2003. Perubahan ini merubah landasan pijak masyarakat yang awalnya menggarap lahan di kawasan menjadi terhenti. Namun dampak kebijakan ini baru diberlakukan di Tahun 2009 semenjak petugas TNGGP datang. Hal ini memicu pertenganan di berbagai pihak. Bagi petani penggarap Kampung
Cipecang wacana penutupan akses tersebut dapat menghilangkan lapangan pekerjaan dan penghasilan sehari-hari. Namun di sisi lain, pihak TNGGP bersikeras untuk tetap melakukan penutupan agar ekosistem dalam kawasan tetap terjaga. Perebutan sumber daya alam di dalam kawasan TNGGP ini menimbulkan konflik emerging yang terjadi di berbagai pihak. Konflik permasalahan sumber daya alam hingga Tahun 2017 semakin kompleks akibat adanya intimidasi yang diterima petani setiap tahunnya.

Simpulan khusus dalam penelitian ini yaitu sebagai berikut:

1. Aktor-aktor yang terlibat dalam konflik meliputi petani penggarap Kampung Cipecang, pihak TNGGP, aparat pemerintah Desa Pasir Buncir, dan RMI. Kemudian, eskalasi konflik dimulai pada Tahun 2009 akibat pemberitahuan pelarangan menggarap di kawasan TNGGP oleh petugas taman nasional kepada petani penggarap Kampung Cipecang. Konflik terjadi akibat ketidakterimaan petani atas kebijakan yang merugikan mereka. Hal ini terus berlanjut hingga Tahun 2016, namun selama periode ini petani selalu mendapatkan perlakuan intimidasi.

2. Faktor-faktor penyebab konflik yang terjadi di kawasan Taman Nasional Gunung Gede Pangrango (TNGGP) disebabkan oleh empat faktor, yaitu perbedaan data, perbedaan kepentingan, masalah hubungan antar manusia, dan masalah struktural. Pada perbedaan data, petani penggarap tidak mengetahui informasi mengenai waktu penetapan dan zonasi yang ada dalam kawasan TNGGP sehingga memunculkan konflik akibat kesalahan dalam pemahaman. Kemudian, perbedaan kepentingan antara petani penggarap dengan pihak TNGGP memicu perebutan kekuasaan sumber daya alam akibat perbedaan kebutuhan. Selanjutnya, masalah hubungan antar manusia disebabkan oleh cara komunikasi yang salah oleh pihak TNGGP kepada petani penggarap. Beberapa petani merasa di intimidasi untuk meninggalkan lahan garapan mereka. Adanya isu penangkapan salah satu petani oleh pihak TNGGP menimbulkan kemarahan petani sehingga mempengaruhi petani lainnya untuk ikut berselisih. Pada masalah struktural disebabkan pembuatan kebijakan dilakukan tanpa adanya koordinasi dan diskusi kepada petani. Munculnya kebijakan pelarangan 
penggarapan di kawasan TNGGP memicu eskalasi konflik.

3. Dampak konflik yang ditimbulkan akibat konflik ini yakni keresahan petani dan ketakutan petani dan peningkatan kohesivitas kelompok. Keresahan dan ketakutan terjadi karena penangkapan Pak SM pada Tahun 2003 oleh petugas Taman Nasional akibat transaksi kayu hasil hutan didalam Padahal, kayu yang dijual kepada orang lain berasal dari lahan garapnya sendiri. Pihak TNGGP berdalih bahwa pengambilan kayu didalam kawasan tersebut merupakan bentuk tindakan pelanggaran karena illegal. Kemudian hal ini menciptakan situasi ketakutan petani apabila masuk kedalam kawasan TNGGP. Sementara itu, dampak konflik menimbulkan situasi positif karena meningkatkan kohesivitas kelompok. Peningkatan tesebut terjadi karena disebabkan oleh adanya persamaan nasib, perasaan iba, dan kumpul rapat petani.

4. Berdasarkan uji korelasi Rank Sperman, terdapat hubungan antara perbedaan data dengan intensitas konflik emerging yaitu sebesar 0.379, sehingga dikategorikan dalam kekuatan hubungan positif yang sedang. Kemudian pada perbedaan kepentingan dengan intensitas konflik emerging terdapat hubungan positif yang kuat dengan nilai sebesar 0.465. Sementara untuk hubungan masalah hubungan manusia dengan intensitas konflik emerging terjadi hubungan positif yang kuat dengan nilai sebesar 0.524 . Pada masalah struktural dengan intensitas konlik emerging terdapat hubungan positif yang kuat dengan nilai sebesar 0.512 .

5. Upaya untuk melakukan penyelesaiaan konflik belum terlaksana. Hal ini disebabkan masih adanya perasaan curiga dari masing-masing pihak sehingga apabila ingin melaksanakan pertemuan sulit terlaksana. Melihat situasi tersebut, diperlukan pihak ketiga yang bersifat netral untuk dapat merealisasikan pertemuan yang dapat menyelesaikan konflik antar mereka. Oleh karena itu diperlukan Community Based Conflict Manajement (CBCM) atau manajemen konflik berbasis komunitas sebagai strategi dalam menyelesaikan konflik yang terus berkelanjutan. Cara yang digunakan untuk pengembangan manajemen konflik yakni mediasi yang dilakukan oleh pihak ketiga.

\section{Saran}

Sesuai dengan hasil-hasil penelitian yang telah dijabarkan sebelumnya dapat dibuat beberapa saran seperti berikut:

1. Adanya berbagai aktor yang terlibat dalam permasalahan konflik ini, diperlukan pertemuan yang melibatkan semua aktor yang terlibat dalam satu forum. Hal ini dapat memberikan kesepahaman baik berupa perumusan ulang kebijakan sehingga memberikan akses kepada petani penggarap, maupun meninjau ulang perundang-undangan yang berhubungan dengan kawasan konservasi dan hak masyarakat lokal sehingga antar aktor yang terkait dapat berkoordinasi dan ikut serta dalam setiap pembuatan kebijakan yang berhubungan dengan lahan garapannya.

2. Pihak TNGGP sebaiknya perlu melakukan evaluasi terhadap petugas lapang pihak TNGGP dalam hal cara berkomunikasi. Hal ini dilakukan agar dapat menghindarkan interaksi yang bersifat intimidasi yang selama ini dirasakan oleh petani penggarap. Selain itu, ini juga dapat mengurangi ketegangan konflik emerging yang terjadi.

3. Dalam mengelola konflik, sebaiknya pengelolaan konflik memperhatikan faktor-faktor penyebab konflik, berupa perbedaan data, perbedaan kepentingan, masalah hubungan antar manusia dan masalah struktural. Faktor-faktor penyebab konflik tersebut berhubungan dengan intensitas konflik. Semakin tinggi salah satu faktornya, misalnya masalah struktural maka intensitas konfliknya semakin tinggi tingkat. Selain itu, dalam mengelola konflik sebaiknya mengacu pada skor uji korelasi tertinggi yakni masalah hubungan antar manusia, sehingga masalah tersebut dapat dikelola terlebih dahulu karena memiliki hubungan yang paling kuat.

4. Dalam melakukan penyelesaian konflik diperlukan pihak ketiga sebagai solusi untuk mencapai musyawarah dengan pandangan yang objektif atau netral. Oleh karena itu, metode manajemen konflik berbasis komunitas atau community based conflict manajemen (CBCM) dipandang cocok untuk mengatasi persoalan konflik yang ada.

\section{DAFTAR PUSTAKA}

Agustinawati LS. 2011. Kontribusi Sumberdaya Hutan terhadap pendapatan masyarakat di sekitar Taman Nasional Gunung Gede 
Pangrango (Studi Kasus di Desa Cinagara dan Desa Pasir Buncir, Kecamatan Caringin, Kabupaten Bogor, Jawa Barat). [Skripsi]. Bogor [ID]: Institut Pertanian Bogor.

Dharmawan AH. 2006. Konflik-sosial dan resolusi konflik: Analisis sosiobudaya. Makalah Seminar dan Lokakarya Nasional Pengembangan Perkebunan Wilayah Perbatasan Kalimantan. [internet]. [diunduh pada 23 Januari 2017]. Tersedia pada: http://mfile.narotama.ac.id/files/Umum/JUR NAL\%20IPB/Konflik-

Sosial\%20dan\%20Resolusi\%20Konflik$\%$ 20Analisis\%20Sosio-

Budaya\%20(Dengan\%20Fokus\%20Perhatia $\mathrm{n} \% 20$ Kalimantan\%20Barat).pdf

Dody. 2014. Resolusi Konflik Perambahan Hutan Taman Nasional Lore Lindu di Dongi-Dongi Provinsi Sulawesi Tengah. [Tesis]. Yogyakarta [ID]: Universitas Gadjah Mada. [internet]. [diunduh pada: 5 Januari 2017]. Tersedia pada: http://etd.repository.ugm.ac.id/index.php?m od=penelitian_detail\&sub=PenelitianDetail \&act=view\&typ $=h$ tml\&buku id $=77269$

Fisher S, Abdi DI, Ludin J, Smith R, Williams S. 2001. Mengelola Konflik: Keterampilan dan Strategi Bertindak. Kartika Sari SN, Tapilatu MD, Maharani R,Rini DN, penterjemah. Terjemahan. Jakarta [ID]: The British Council.

Fitriyah, Manar DG. 2011. Anatomi Konflik Sosial Di Jawa Tengah: Studi Kasus Konflik Penistaan Agama di Temanggung. Jurnal Ilmu Politik. 2 (2), 1-13. [internet]. [diunduh pada 23 Janurari 2017]. Tersedia pada: http://

ejournal.undip.ac.id/index.php/politika/artic le/viewFile/4938/4477

Fuad F, Maskanah S. 2000. Inovasi Penyelesaian Sengketa Pengelolaan Sumberdaya Hutan. Bogor [ID]: Pustaka LATIN.

Hidayah A. 2012. Manajemen Konflik Pengelolaan Sumberdaya Hutan Berbasis Komunitas (Studi Kasus: Konsep PHBM di KPH Randublatung, Kabupaten Blora, Provinsi Jawa Tengah) [Skripsi]. Bogor [ID]: Institut Pertanian Bogor.
Ilham M. 2006. Analisa konflik pengelolaan sumberdaya alam masyarakat desa sekitar hutan (Kasus masyarakat Desa Curugbitung, Kecamatan Nanggung, Kabupaten Bogor, Propinsi Jawa Barat). [Skripsi]. Bogor [ID]: Institut Pertanian Bogor.

Karlinda E. 2015. Konflik Perluasan Kawasan Konservasi Taman Nasional Gunung Gede Pangrango di Desa Wates Jaya, Kecamatan Cigombong, Kabupaten Bogor. [Skripsi]. Bogor [ID]: Institut Pertanian Bogor.

Karsodi ERJ. 2007. Analisis konflik areal eks tumpang sari Perum Perhutani di wilayah perluasan Taman Nasional Gunung Gede Pangrango (Kasus di Dusun Gunung Putri, Desa Sukatani, Resort Gunung Putri, Seksi Konservasi Wilayah III Cianjur Taman Nasional Gunung Gede Pangrango). [skripsi]. [Internet]. [diunduh tanggal 23 Januari 2017]. Dapat diunduh dari: http://repository.ipb.ac.id/handle/12345678 9/49170.

Kausar. 2010. Konflik Kepentingan Dibalik Konservasi Studi Di Taman Nasional Kerinci Seblat (TNKS) Provinsi Jambi. Jurnal Ekonomi Pertanian. 2 (1), 132-149. [internet]. [diunduh pada 1 Desember 2016]. Tersedia pada: http://ejournal.unri.ac.id/index.php/IJAE/art icle/viewFile/471/464

Kinseng RA. 2013. Identifikasi Potensi, Analisis, dan Resolusi Konflik. Dalam: Nikijuluw VPH, Adrianto L, Januarini N, editor. Coral Governance. Bogor [ID]: IPB Press.

Maharani S. 2008. Sikap Rasional Petani dan Konflik Pemanfaatan Lahan Pertanian di Perdesaan (Studi Kasus Desa Cibatok Satu, Kecamatan Cibungbulang, Kabupaten Bogor, Provinsi Jawa Barat). [Skripsi]. Bogor [ID]: Institut Pertanian Bogor.

Mangindaan EE. 1999. Pertemuan Regional Pengelolaan Taman Nasional Kawasan Timur Indonesia. [internet]. [diunduh pada 23 Januari 2017]. Tersedia pada pdf.usaid.gov/pdf_docs/Pnach574.pdf

Marina I, Dharmawan AH. 2011. Analisis Konflik Sumberdaya Hutan Di Kawasan Konservasi. Jurnal Transdisiplin Sosiologi, Komunikasi, dan Ekologi Manusia. 5 (2): 90-96. 
[internet]. [diunduh pada 1 Desember 2016]. Tersedia pada: http://download.portalgaruda.org/article.php ? article $=83505 \& \mathrm{val}=223$

Miranda JJ, Corral L, Blackman A, Asner G, Lima E. 2014. Effects of Protected Areas on Forest Cover Change and Local Communities Evidence from the Peruvian Amazon, Environment for Development. Artikel Ilmiah. Washington (US). [Internet]. [Diunduh tanggal 1 Desember 2016]. Tersedia pada http://www.rff.org/search/google/Effects $\% 2$ 0of $\% 20$ Protected $\% 20$ Areas $\% 20$ on $\% 20$ Fore st $\% 20$ Cover $\% 20$ Change $\% 20$ and $\% 20$ Local $\% 20$ Communities $\% 20$ Evidence $\% 20$ from $\%$ 20the\%20Peruvian\%20Amazon

Mufrizal. 2010. Upaya Penanggulangan Perambahan pada Kawasan Taman Nasional Gunung Ciremai dalam Perspektif Undang-Undang Nomor 5 Tahun 1990 Tentang Konservasi Sumberdaya Alam Hayati dan Ekosistemnya [tesis]. [diunduh 28 Oktober 2016]. Surakarta [ID]: Universitas Sebelas Maret. Tersedia pada: http://dglib.uns.ac.id/dokumen/download/

Musdalifah. 2009. Konflik Agraria Dalam Relasi Antara Perusahaan Pertambangan Dengan Masyarakat (Kasus Konflik Antara Petani Dengan PP.PP Lonsum di Kabupaten Bulukumba). Jurnal Disertasi. [internet]. [diunduh pada: 23 Januari 2017]. Tersedia pada

http://pasca.unhas.ac.id/jurnal/files/f37a36b 6ee43f77056c67e2905ac9798.pdf

Nasdian FT. 2014. Pengembangan Masyarakat. Jakarta (ID): Yayasan Pustaka Obor Indonesia

Oktaviana. 2015. Analisis Sumber Daya Alam di Pegunungan Kendeng Utara, Kabupaten Pati, Provinsi Jawa Tengah (Studi Kasus: Rencana Pembangunan Pabrik Semen oleh PT. SMS di Kecamatan Tambakromo dan Kayen). [Skripsi]. Bogor [ID]: Institut Pertanian Bogor.

Prabowo SA, Basuni S, Suharjito D. 2010. Konflik Tanpa Henti: Permukiman dalam Kawasan Taman Nasional Halimun Salak. Jurnal Manajemen Hutan. 16 (3): 137-142. [internet]. [diunduh pada: 1 Desember 2016]. Tersedia pada http://journal.ipb.ac.id/index.php/jmht/articl e/view/3176

Pruitt DG, Rubin, JZ. 2009. Teori Konflik Sosial. Yogyakarta [ID]: Pustaka Pelajar.

Risyandra Z. 2012. Konflik Penguasaan Lahan di Kecamatan Kertajati (Studi Kasus Pembangunan Bandara di Desa Sukamulya, Kecamatan Kertajati, Kabupaten Majalengka, Provinsi Jawa Barat). [Skripsi]. Bogor [ID]: Institut Pertanian Bogor.

Sabira EJ. 2006. Pemetaan Konflik Pengelolaan Sumberdaya Hutan di Hutan Lindung Gunung Lumut Kabupaten Pasir Provinsi Kalimantan Timur. [Skripsi]. Bogor [ID]: Institut Pertanian Bogor.

Singarimbun M, Effendi S. 1989. Metode Penelitian Survei. Jakarta [ID]: LP3ES.

Sujarweni. 2014. SPSS Untuk Penelitian. Yogyakarta [ID]: Pustaka Baru Press.

Tadjudin D. 1999. Model Kelembagaan Masyarakat dalam Pengelolaan Hutan Alam Produksi. Jurnal Seri Kajian Komuniti Forestri Seri 3 Tahun 2. Bogor. LATIN.

Tadjudin D. 2000. Manajemen Kolaborasi. Bogor [ID]: Pustaka LATIN.

Tukiran dan Effendi. 2014. Metode Penelitian Survei. Edisi Revisi. Jakarta [ID]: LP3ES

Wirajardjo B, et al. 2001. Konflik, Bahaya atau Peluang? Panduan Latihan Menghadapi dan Menangani Konflik Sumberdaya Alam. Bandung [ID]: Kerjasama Badan Pelaksana Konsorsium Pembaruan Agraria (BP-KPA) dengan BSPKemala.

Wulan YC, Yasmi Y, Purba C, Wollenberg E. 2004. Kasus HTI Perum Perhutani Unit I, Jawa Tengah. [Internet]. [Diunduh tanggal 1 Desember 2016]. Tersedia pada www.cifor.org/publications/pdf_files/Books/B Wulan040110.pdf 